\title{
PENGARUH LATIHAN TEHNIK SLOW BREATHING EXERCISE TERHADAP PENURUNAN TEKANAN DARAH PADA PASIEN HIPERTENSI ESENSIAL
}

\author{
The Influence of Slow Breathing Exercise Technique to the Blood Pressure Decrease At \\ The Essential Hypertension Patients
}

Frengki Apryanto

STIKES Widyagama Husada Malang, E-mail: frenky_apryanto@yahoo.com

\begin{abstract}
Background: Hypertension often be called as silent killer, because included as deadly disease, without symptoms as the warning to the victims. The Diseases Integrated Surveillance of Health Care Center in East Java in 2010, some areas in East Java that contribute hypertension mostly are Malang city of 31.789 persons. The research aimed at studying the differences of blood pressure before and after slow breathing exercises at the essential hypertension patients. Method: The research method was pre experimental of one group pre test - post test with dependent variable of blood pressure and the independent variable was the slow breathing exercises technique. The sampling technique is purposive sampling with 98 respondents who were examined at the health care center of Malang city, suitable with the inclusion criteria. The patients were given slow breathing exercises technique by regulating the chest and abdomen breathing by take a breath from nose, and exhale slowly from mouth 6-10 times per minute for \pm 15 minutes twice a day (morning and afternoon) for 30 days in succession.

Result: The analysis results by paired sample t test known that from 98 respondents before given slow breathing exercises have blood pressure of 153.63/96.47 $\mathrm{mmHg}$, than after given slow breathing exercises have 145.16/88.5 $\mathrm{mmHg}$.

Conclusion: The conclusion of the research is the blood pressure mean after given slow breathing exercises experience decrease compared with before the exercises. It means there is influence of slow breathing exercises to the decrease of blood pressure of the essential hypertension patients. The slow breathing exercises technique should be applied to health services institution as the complementary therapy for medical therapy.
\end{abstract}

Keywords :Slow breathing exercises technique, blood pressure 


\begin{abstract}
ABSTRAK
Hipertensi seringkali disebut sebagai silent kiler, karena termasuk penyakit mematikan, tanpa disertai dengan gejala-gejalanya lebih dahulu sebagai peringatan bagi korbannya. Gejala tersebut seringkali dianggap sebagai gangguan biasa, sehingga korbannya terlambat menyadari akan datangnya penyakit.Data Surveilans Terpadu Penyakit (STP) Puskesmas di Jatim 2010, sejumlah daerah di Jatim yang paling banyak menyumbang pasien penderita hipertensi adalah Kabupaten Malang dengan jumlah penderita 31.789 orang. Tujuan penelitian ini mengetahui perberbedaan tekanan darah sebelum dan sesudah pemberian latihan tehnik slow breathing exercises pada pasien hipertensi esensial.Mengetahui efektivitas latihan tehnik slow breathing exercises terhadap penurunan tekanan darah pada pasien hipertensi esensial.Metode dalam penelitian ini adalah pra eksperimentalOne Group Pretest-Postestdengan variabel dependent tekanan darah dan variabel independent adalah latihan teknik slow breathing exercises. Tehnik samplingnya adalah purposive sampling denganjumlah 98 responden yang melakukan pemeriksaan tekanan darah di poli Rumah Sakit Islam Malang sesuai dengan kriteria inklusi. Pasien diberikan latihan teknik slow breathing exercises dengan cara mengatur pernafasan dada dan perut dengan menarik nafas dalam dari hidung, menghembuskan dengan perlahan-lahan dari mulut 6-10 kali per menit selama \pm 15 menit $2 \mathrm{x}$ sehari (pagi dan sore) selama 30 hari berturut-turut.Hasil analisis dengan uji paired sampel t test menunjukkan bahwa rerata tekanan darah pada responden sebelum diberikan latihan teknik slow breathing exercises adalah 153,63/96,47 mmHg.Rerata tekanan darah responden setelah diberikan latihan teknik slow breathing exercises adalah 145,16/ 88,5 mmHg.Kesimpulan dalam penelitian ini yaitu rerata tekanan darah setelah diberikan latihan teknik slow breathing exercisesmengalami penurunan dibandingkan tekanan darah sebelum diberikan latihan. Hal ini berarti ada pengaruh latihan teknik slow breathing exercises terhadap penurunan tekanan darah pada pasien hipertensi esensial. Latihan teknik slow breathing exercisesuntuk menurunkan tekanan darah pada pasien hipertensi esensial hendaknya diaplikasikan di institusi pelayanan kesehatan sebagai terapi komplementer pendamping terapi medis.
\end{abstract}

\title{
Kata kunci :Teknik slow breathing exercises, Tekanan Darah.
}

\section{PENDAHULUAN}

Penyakit hipertensi adalah fenomena global dan biasanya terjadi pada semua populasi manusia. Hidup modern yang penuh kesibukan, kerja keras dan stress membuat orang kurang berolahraga, dan berusaha mengatasi stresnya dengan merokok, minum alkohol atau kopi. Jenis makanan dan minuman yang mengandung bahan pengawet, lemak, garam dan bahan penyedap lebih digemari untuk dikonsumsi masyarakat. Gaya hidup yang tidak sehat ini menyebabkan timbulnya penyakit hipertensi (Sustrani, 2004).

Hipertensi seringkali disebut sebagai silent kiler, karena termasuk penyakit mematikan, tanpa disertai dengan gejalagejalanya lebih dahulu sebagai peringatan bagi korbannya. Gejala tersebut seringkali dianggap sebagai gangguan biasa, sehingga korbannya terlambat menyadari akan datangnya penyakit.
Hipertensi adalah penyakit yang makin banyak dijumpai di Indonesia, terutama di kota-kota besar. Hipertensi merupakan faktor risiko langsung terhadap timbulnya infark miokard dan CVA (cerebrovascular accident) (Tambayong, 2000:94). Berdasarkan data statistik 2006 dari American Heart Association, enam puluh juta pria dan wanita di Amerika Serikat menderita tekanan darah tinggi. Persentase penderita hipertensi dikalangan kulit putih adalah 20,5, sedangkan di kalangan kulit hitam 31,6. Sembilan belas persen penduduk keturunan Hispanik dan 16,1\% keturunan Asia menderita hipertensi. Data prevalensi tersebut berkontribusi atas 7,2 juta serangan jantung dan 5,5 juta stroke dalam setahun. (Kowalski, 2010). Hasil Riset Kesehatan Dasar (Riskesdas) tahun 2007 oleh Badan Penelitian dan Pengembangan Kemenkes RI menunjukkan prevalensi hipertensi nasional sebesar 
$31,7 \%$, sebagian besar kasus hipertensi di masyarakat belum terdiagnosis (Riskesdas, 2007).

Data Dinas Kesehatan Jawa Timur menyebutkan, total penderita hipertensi di Jatim 2011 sebanyak 285.724 pasien. Data ini diambil menurut Surveilans Terpadu Penyakit (STP) Puskesmas di Jatim. Jumlah tersebut terhitung mulai bulan Januari hingga September. Jumlah penderita tertinggi pada bulan Mei sebanyak 46.626 pasien. Surveilans Terpadu Penyakit (STP) Puskesmas di Jatim 2010, sejumlah daerah di Jatim yang paling banyak menyumbang pasien penderita hipertensi adalah Kabupaten Malang dengan jumlah penderita 31.789 orang. Disusul Surabaya menduduki peringkat ke-2 jumlah 28.970 penderita. Madura menduduki rangking 3 sebanyak 28.955 penderita. Daerah Bangkalan sebanyak 11.292 penderita, Pamekasan 313 penderita, Sampang 8933 penderita dan Sumenep 8417 penderita. Jumlah penderita hipertensi di Jatim mencapai 275 ribu orang. Intervensi yang dilakukan di puskesmas tersebut masih menggunakan terapi medis dengan memberikan obat-obatan dan edukasi pola makan pada pasien hipertensi.

Penelitian dengan terapi perilaku non farmakologi dalam menurunkan tekanan darah telah banyak dilakukan, baik dalam negeri maupun di luar negeri. Salah satu penelitian diluar negeri tersebut dilakukan oleh Grossman (2001) yang dilakukan pada penderita hipertensi primer. Hasil penelitian menunjukkan terjadi perubahan tekanan darah pada kelompok perlakuan yaitu -5/2,7 $\mathrm{mm} \mathrm{Hg}$ dibanding pada kelompok pembanding yaitu $-1,2 /+0.9 \mathrm{~mm} \mathrm{Hg}$. Latihan slow breathing exercises selama 10 menit setiap hari merupakan cara efektif modalitas non farmakologis untuk menurunkan tekanan darah

Penanganan hipertensi meliputi kombinasi pemberian obat, pengaturan diet, dan olah raga. Penanganan hipertensi secara non-medis dapat dilakukan dengan integrative medicine yaitu teknik relaksasi. Latihan tehnik slow breathing exercises dapat diajarkan pada pasien untuk menurunkan tekanan darah. Teknik slow breathing exercises sampai saat ini jarang dilakukan penelitian yang mengkaji pengaruh latihan teknik slow breathing exercises terhadap penurunan tekanan darah pada pasien hipertensi.

Proses keperawatan dalam penelitian ini didasarkan pada paradigma model adaptasi Roy. Sakit terjadi jika individu tidak mampu beradaptasi secara holistis dari stresor yang didapatkan. Intervensi keperawatan bertujuan sebagai stimulus terhadap stres (sakit) yang berperan memperbaiki jenis koping (cognator) individu melalui proses pembelajaran yaitu latihan teknik slow breathing exercises.

\section{BAHAN DAN METODE}

Metode dalam penelitian ini adalah pra eksperimental One Group PretestPostest dengan variabel dependent tekanan darah dan variabel independent adalah latihan teknik slow breathing exercises. Tehnik samplingnya adalah purposive sampling denganjumlah 98 responden yang melakukan pemeriksaan tekanan darah di poli Rumah Sakit Islam Malang sesuai dengan kriteria inklusi terhitung mulai tanggal 22 Oktober sampai dengan 30 Nopember 2015. Pasien diberikan latihan teknik slow breathing exercises dengan cara mengatur pernafasan dada dan perut dengan menarik nafas dalam dari hidung, menghembuskan dengan perlahan-lahan dari mulut 6-10 kali per menit selama \pm 15 menit $2 x$ sehari (pagi dan sore) selama 30 hari berturut-turut.

\section{HASIL}

Pengumpulan data dilakukan sejak tanggal 22 Oktober sampai 30 Nopember 2013. Didapatkan 98 responden pada pasien dengan diagnosa hipertensi sesuai kriteria inklusi.

Tabel .1 Karakteristik responden penelitian pengaruh latihan tehnik slow breathing exercises terhadap penurunan tekanan darah pada pasien hipertensi esensial periode tahun 2015 


\begin{tabular}{|c|c|c|}
\hline $\begin{array}{c}\text { Karakteristi } \\
\mathbf{k}\end{array}$ & $\begin{array}{c}\text { Frekwens } \\
\text { i } \\
\text { (f) } \\
\end{array}$ & $\begin{array}{c}\text { Persentas } \\
\text { e } \\
(\%) \\
\end{array}$ \\
\hline $\begin{array}{l}\text { Jenis } \\
\text { Kelamin: } \\
\text { Laki-laki } \\
\text { Perempuan }\end{array}$ & $\begin{array}{l}41 \\
57\end{array}$ & $\begin{array}{l}42 \\
58\end{array}$ \\
\hline Total & 98 & 100 \\
\hline $\begin{array}{l}\text { Usia: } \\
\text { 26-35 tahun } \\
36-45 \text { tahun } \\
46-55 \text { tahun } \\
\text { 56-65 tahun } \\
\text { Total }\end{array}$ & $\begin{array}{l}15 \\
22 \\
28 \\
33 \\
98\end{array}$ & $\begin{array}{c}15 \\
22 \\
29 \\
34 \\
100\end{array}$ \\
\hline $\begin{array}{l}\text { Pendidikan: } \\
\text { SD } \\
\text { SMP } \\
\text { SMA } \\
\text { Diploma } \\
\text { Sarjana } \\
\end{array}$ & $\begin{array}{l}12 \\
20 \\
40 \\
14 \\
12\end{array}$ & $\begin{array}{l}12 \\
20 \\
41 \\
14 \\
12 \\
\end{array}$ \\
\hline Total & 98 & 100 \\
\hline $\begin{array}{l}\text { Pekerjaan: } \\
\text { IRT } \\
\text { PNS } \\
\text { SWT } \\
\text { Total }\end{array}$ & $\begin{array}{l}43 \\
10 \\
45 \\
98\end{array}$ & $\begin{array}{c}44 \\
10 \\
46 \\
100\end{array}$ \\
\hline $\begin{array}{l}\text { Terapi: } \\
1 \text { obat } \\
\text { Kombinasi } \\
\text { Total }\end{array}$ & $\begin{array}{l}71 \\
27 \\
98\end{array}$ & $\begin{array}{c}72 \\
28 \\
100\end{array}$ \\
\hline
\end{tabular}

Analisis pengaruh latihan tehnik slow breathing exercises terhadap penurunan tekanan darah pada pasien hipertensi.

Tabel .2 Rerata sistole, diastole, dan $p-$ Value sebelum dan sesudah latihan teknik slow breathing exercisespada pasien hipertensi

\begin{tabular}{|c|c|c|c|c|}
\hline \multirow[b]{2}{*}{$\begin{array}{l}\text { Tekana } \\
\text { n darah }\end{array}$} & \multicolumn{2}{|c|}{ Sebelum } & \multicolumn{2}{|c|}{ Sesudah } \\
\hline & Rerata & $\begin{array}{c}p- \\
\text { valu } \\
e\end{array}$ & Rerata & $\begin{array}{c}p- \\
\text { valu } \\
e\end{array}$ \\
\hline Sistole & $\begin{array}{c}153,6 \\
3\end{array}$ & $\begin{array}{c}0,00 \\
0\end{array}$ & $\begin{array}{c}145,1 \\
6\end{array}$ & $\begin{array}{c}0,00 \\
0\end{array}$ \\
\hline $\begin{array}{l}\text { Diastol } \\
\mathrm{e}\end{array}$ & 96,47 & $\begin{array}{c}0,00 \\
0\end{array}$ & 88,5 & $\begin{array}{c}0,00 \\
0\end{array}$ \\
\hline
\end{tabular}

Hasil analisis dengan uji paired sampel t test pada tabel 5.2 dapat diketahui bahwa dari 98 responden hipertensi sebelum diberikan latihan slow breathing exercises memiliki rerata tekanan darah 153,63/96,47 $\mathrm{mmHg}$, setelah diberikan latihan slow breathing exercises memiliki rerata tekanan darah $145,16 / 88,5 \mathrm{mmHg}$. Selisih rerata tekanan darah sistole sebelum dan sesudah latihan slow breathing exercises adalah $8,4 \mathrm{mmHg}$, sedangkan selisih rerata tekanan darah diastole sebelum dan sesudah latihan slow breathing exercises adalah 7,9 mmHg.Output SPSSmemberikan nilai $p$-value untuk uji dua sisi $(2$-tailed $)=0,000$. Nilai $p$-value untuk uji satu sisi ini lebih kecil dari $\alpha=$ 0,05 , sehingga merupakan bukti kuat menolak $\mathrm{H}_{0}$. Kesimpulan rerata (mean) tekanan darah setelah diberikan latihan teknik slow breathing exercises mengalami penurunan dibandingkan tekanan darah sebelum diberikan latihan. Hal ini berarti ada pengaruh latihan teknik slow breathing exercises terhadap penurunan tekanan darah pada pasien hipertensi esensial.

\section{PEMBAHASAN}

Analisis Tekanan Darah pada Pasien Hipertensi Esensial Sebelum Pemberian Latihan Teknik Slow Breathing Exercises.

Tekanan darah rerata pada responden sebelum diberikan latihan teknik slow breathing exercises adalah 153,63/96,47 mmHg. Rerata tekanan darah pada responden sebelum diberikan latihan teknik slow breathing exercises sesuai dengan klasifikasi hipertensi menurut JNC VII berada pada stage I yaitu tekanan darah sistolik 140-159 mmHg dan tekanan darah diastolik 90-99 mmHg.

Hasil penelitian yang dilakukan oleh Sigarlaki 2006, pengolahan distribusi umur terhadap hipertensi, didapatkan bahwa responden yang menderita pre hipertensi berusia 56-77 tahun (8,82 \%), sementara yang menderita hipertensi grade I $(28,43 \%)$ dan yang menderita hipertensi grade II $(18,65 \%)$. Hal ini disebabkan karena pada usia tersebut arteri besar kehilangan kelenturannya dan menjadi kaku karena itu darah pada setiap denyut jantung dipaksa untuk melalui pembuluh yang sempit 
daripada biasanya dan menyebabkan naiknya tekanan.

Pengukuran tekanan darah yang benar dan interprestasi yang tepat dari tekanan darah sangat penting dalam diagnosis dan pengelolaan hipertensi. Ketepatan kalibrasi alat tekanan darah, terlatih atau tidaknya personil, posisi dari pasien saat dilakukan pengukuran, waktu pengukuran, riwayat pengobatan sebelumnya, teknik pengukuran dan pemilihan ukuran besar manset semuanya menjadi faktor penting dalam ketepatan pengukuran tekanan darah (Departemen/ SMF Kardiologi dan Kedokteran Vaskuler Universitas Airlangga-RSUD Dr Soetomo, 2012).

Variabel lain yang dapat mempengaruhi tekanan darah adalah asupan makanan, latihan berat, merokok dan konsumsi kafein. Merokok menimbulkan kenaikan tekanan darah, dengan demikian tekanan darah di klinik mungkin menjadi bias pada seorang perokok berat. Asupan kafein dapat meningkatkan tekanan darah secara akut, terutama pada peminum kopi yang nonhabitual. Pengukuran tekanan darah di ruangan yang sejuk atau saat pasien berbicara dapat meningkatkan nilai yang terukur sebanyak 8 sampai $15 \mathrm{mmHg}$.

Analisis Tekanan Darah pada Pasien Hipertensi Esensial Setelah Pemberian Latihan Teknik Slow Breathing Exercises.

Rerata tekanan darah responden setelah diberikan latihan teknik slow breathing exercises adalah 145,16/ 88,5 $\mathrm{mmHg}$. Rerata tekanan darah pasien setelah diberikan latihan berada pada klasifikasi hipertensi stage 2, namun tekanan darah sistolik mengalami penurunan klasifikasi pada prehipertensi yaitu $80-89 \mathrm{mmHg}$. Penelitian yang dilakukan oleh Grossman, breathing control lowers blood pressure, menunjukkan bahwa pada kelompok perlakuan mengalami penurunan diastolik rata-rata $7,7 \mathrm{mmHg}$.

Curah kerja otot meningkatkan konsumsi oksigen, dan selanjutnya konsumsi oksigen akan melebarkan pembuluh darah otot, sehingga meningkatkan aliran balik vena dan curah jantung. Suatu peningkatan tekanan darah merangsang reseptor-reseptor dalam sinus karotid dan arkus aorta. Impuls aferen yang timbul setelah relai di dalam nukleus solitarius (NTS) dalam batang otak, menekan pusat simpatik batang otak. Arkus refleks baroreseptor ini membentuk loop umpan balik negatif yang di dalamnya timbul kenaikan tekanan arterial bila ada penghambatn aliran simpatik sentral (Harisson, 1999).

Pemberian latihan teknik slow breathing exercises pada pasien hipertensi dengan usia lansia dalam penelitian ini kurang efektif, hal ini berkaitan dengan faktor disfungsi endotel dan meningkatnya kekakuan pembuluh darah. Hal ini mungkin melalui gangguan produksi nitrit oksida yang tidak dapat berespon terhadap perubahan dalam kondisi intravaskular untuk konstriksi dan dilatasi bila diperlukan.

Analisis Pengaruh Latihan Tehnik Slow Breathing Exercises terhadap Penurunan Tekanan Darah pada Pasien Hipertensi Esensial

Berdasarkan analisis dengan uji paired sampel $t$ test pada tabel 5.2 dapat diketahui bahwa dari 98 responden hipertensi sebelum diberikan latihan slow breathing exercisesmemiliki rerata tekanan darah sistole 153,63/96,47 $\mathrm{mmHg}$, setelah diberikan latihan slow breathing exercisesmemiliki rerata tekanan darah $145,16 / 88,5 \mathrm{mmHg}$. Nilai $p$-value untuk uji dua sisi $(2$-tailed $)=0,000$. Nilai $p$-value untuk uji satu sisi ini lebih kecil dari $\alpha=$ 0,05, sehingga merupakan bukti kuat menolak $\mathrm{H}_{0}$. Kesimpulan rerata (mean) tekanan darah setelah diberikan latihan teknik slow breathing exercisesmengalami penurunan dibandingkan tekanan darah sebelum diberikan latihan. Hal ini berarti ada pengaruh latihan teknik slow breathing exercises terhadap penurunan tekanan darah pada pasien hipertensi.

Pengukuran tekanan darah dilakukan 15 menit setelah pasien melakukan latihan slow breathing exercises. Pengukuran tekanan darah dilakukan dalam posisi duduk dengan punggung yang bersandar. Tekanan darah diukur sebelum obat antihipertensi diminum, hal ini 
dimaksudkan untuk memperkirakan efek potensiasi obat antihipertensi dan untuk menghindari faktor perancu apakah penurunan tekanan darah disebabkan latihan atau efek dari obat antihipertensi.

Pemberian latihan slow breathing exercises pada pasien hipertensi selama 30 hari memberikan efek yang bermakna terhadap penurunan sistole dan diastole. Latihan deep breathing exercisesselama 30 hari berturut-turut sedikitnya dua kali dalam sehari. Selain karena pengaruh terpai farmakologis, responden menyatakan lebih rileks setelah melakukan latihan deep breathing exercises. Kondisi rileks ini berpengaruh terhadap relaksasi otot polos vaskuler sehingga arteri mampu bervasodilatasi secara optimal.

Peningkatan stimulasi reseptor regang kardiopulmonal akan menurunkan impuls simpatif efferen, sehingga terjadi vasodilatasi. Proses ini disertai dengan perubahan 'pernapasan torakal' dengan amplitudo yang lebih kecil menjadi ' 'pernapasan abdominal' dengan amplitudo yang lebih besar, dimana kecepatan yang lebih lambat menggunakan energi dengan lebih efisien (Joseph, 2008).

Mekanisme saraf untuk pengaturan tekanan arteri yang paling diketahui adalah refleks baroreseptor. Refleks ini dimulai oleh reseptor regang, yang disebut baroreseptor atau presoreseptor, yang terletak di dinding beberapa arteri sistemik besar. Peningkatan tekanan akan meregangkan baroreseptor dan menyebabkannya menjalarkan sinyal menuju sistem saraf pusat, dan sinyal umpan balik kemudian dikirim kembali melalui sistem saraf autonom ke sirkulasi untuk mengurangi tekanan arteri tadi kembali ke nilai normal (Guyton, 2006).

Pengaturan tekanan darah intermediet dan jangka panjang juga berperan dalam penurunan tekanan darah seperti nitrogen oksida. NO dihasilkan oleh sel endotel normal sebagai respon terhadap berbagai rangsangan termasuk salah satunya karena perubahan tekanan darah, adanya shear stress dan regangan pulsatile. NO juga berperan penting dalam pengaturan tekanan darah, trombosis dan proses
aterosklerosis.Nitrat oksida berdifusi melalui sel endotelial ke sel otot polos di bawahnya, menyebabkan relaksasi endoteldependen pada otot polos. Pelepasan juga terjadi pada penguraian aliran darah melalui suatu pembuluh, sehingga vasodilatasi lokal mikrovaskular dapat diimbangi oleh dilatasi arteri kecil dan arteriol (Corwin, 2009).

\section{KESIMPULAN DAN SARAN}

\section{Kesimpulan}

Setelah dilakukan analisis hasil dan pembahasan maka penelitian ini dapat disimpulkan bahwa; a) Rerata tekanan darah pada responden sebelum diberikan latihan teknik slow breathing exercises adalah 153,63/96,47 $\mathrm{mmHg}$, b) Rerata tekanan darah responden setelah diberikan latihan teknik slow breathing exercises adalah 145,16/ 88,5 $\mathrm{mmHg}$, c) Pengaruh tekanan darah sebelum dan sesudah pemberian latihan teknik slow breathing exercisesada perbedaan penurunan tekanan darah yang bermakna sebelum dan sesudah pemberian latihan teknik slow breathing exercisespada pasien hipertensi esensial.

\section{Saran}

Berdasarkan kesimpulan di atas, peneliti dapat memberikan saran sebagai berikut; a) Latihan teknik slow breathing exercisessebaiknya dilakukan secara berkelanjutan, sehingga dapat diperoleh efek jangka panjang untuk mencegah komplikasi hipertensi, b) Bagi teman sejawat yang bekerja di intitusi pelayanan hendakanya mengaplikasikan latihan teknik slow breathing exercisesuntuk menurunkan tekanan darah pada pasien hipertensi esensial sebagai terapi komplementer pendamping terapi medis, c) Bagi peneliti selanjutnya hendaknya menggunakan responden kelompok pembanding atau kontrol dalam melakukan penelitian latihan teknik slow breathing exercisesuntuk menurunkan tekanan darah pada pasien hipertensi esensial dan menganalisis faktor perancu dalam penelitian. 
DAFTAR PUSTAKA

Anna, Palmer, 2007, Simple guides: tekanan darah tinggi, Erlangga, Jakarta.

Asih, Niluh gede Yasmin, 2008, Keperawatan medikal bedah: klien dengan gangguan sistem pernapasan, EGC, Jakarta.

Baradero, Mary, 2008,Seri asuhan keperawatan klien gangguan kardiovaskuler, EGC, Jakarta.

Brashers, Valentina L, 2007,Aplikasi klinis patofisiologi: pemeriksaan dan manajemen, EGC, Jakarta.

Corwin, Elizabeth J, 2009, Paofisiologi:buku saku. EGC, Jakarta.

Dalimartha, Setiawan, dr, 2008, Care your self, hipertensi. Penebar Plus, Jakarta.

Gray, Huon H. 2005,Lecture notes: kardiologi, Erlangga, Jakarta.

Grossman,

A,Breathing-control lowersbloodpressure.http://www. nature.com/jhh/journal/v15/n4/abs 11001147a.html.[Access: July 11, 2013].

Gunawan, L. 2007,Hipertensi tekanan darah tinggi, Kanisius, Yogyakarta.

Guyton A, Hall John E. 2006, Buku ajar fisiologi kedokteran, EGC, Jakarta.

Harisson, 1999, Prinsip-prinsip ilmu penyakit dalam vol. I. E/13, EGC, Jakarta.

Harry, Wied, 2007,makan enak untuk hidup sehat, bahagia, dan awet muda. Gramedia Pustaka Utama, Jakarta.

Izzo, Joseph L, 2008, Hypertension primer: the essentials of high blood pressure, Council for High Blood Pressure Research (American Heart Association), USA.

Joewana, Satya, 2008, Gangguan mental dan perilaku akibat penggunaan zat psikoaktif. EGC, Jakarta.

Kabo, $\quad$ Peter, 2008,Mengungkap pengobatan penyakit jantung koroner, PT Gramedia Pustaka Utama, Jakarta.

Klabunde, Richard E, 2012, Cardiovascular physiology concepts 2nd ed, Lippincott Williams \& Wilkins, a Wolters Kluwer business, Philadelphia

Kowalski, Robert E, 2010,Terapi hipertensi: program 8 minggu menurunkan tekanan darah tinggi dan mengurangi risiko serangan jantung dan stroke secara alami. Qanita, Bandung.

Kozier and Erb's, 2009, Buku ajar praktik keperawatan klinis, EGC ,Jakarta.

Muttaqin, Arif, 2009, Pengantar asuhan keperawatan klien dengan gangguan sistem kardivaskuler, Salemba medika, jakarta.

Notoatmodjo, 2010, Metodologi penelitian kesehatan, Rineka Cipta, Jakarta.

Nursalam, 2008, Proses dan dokumentasi keperawatan; konsep dan praktik edisi 2, Salemba Medika, Jakarta

Nursalam, 2008, Konsep dan penerapan metodologi penelitian ilmu keperawatan; pedoman skripsi, tesis, dan instrumen penelitian keperawatan, Salemba Medika, Jakarta

Rahajeng, Ekpwati, 2009. Prevalensi Hipertensi dan Determinannya di Indonesia. Majalah Kedokteran Indonesia, vol. 5, no. 12

Ranganathan, Narasimhan, 2006, The art and science of cardiac physical examination : with heart sounds and pulse wave forms on $C D$, Humana Press, New Jersey.

Ronny, 2009, Fisiologi kardiovaskular: berbasis masalah keperawatan, EGC, Jakarta.

Sigarlaki, Herke, 2006. Karakteristik dan faktor yang berhubungan dengan hipertensi, Majalah Kedokteran Indonesia, vol. 10, no. 2

Sudoyo, Aru, 2006,Buku ajar ilmu penyakit dalam, Departemen ilmu penyakit dalam, Jakarta.

Sutomo, Budi, 2009. Menu sehat penakluk hipertensi, DeMedia Pustaka, Jakarta.

Sustrani, Lanny. \& Alam, S, 2004,Hipertensi, PT Gramedia Pustaka Utama, Jakarta.

Tambayong ,jan, dr, 2000, Patofisiologi untuk keperawatan, EGC, Jakarta. 
JURNAL ILMIAH KESEHATAN MEDIAHUSADA ｜ VOLUME 05/NOMOR 01/MARET 2016

VITA HEALTH, 2008,Hipertensi. PT

Gramedia Pustaka Utama, Jakarta. 